\title{
Proceeding
}

6th INSHS International Christmas Sport Scientific Conference, 11-14 December 2011. International Network of Sport and Health Science. Szombathely, Hungary

\section{School: a coloured world af a everyday reality performance analysis: motor project of educational research for an effective integration}

\author{
MANUELA VALENTINI ${ }^{1}$, ELISA MEZZELANI ${ }^{2}$, GIORGIA MARZIANI ${ }^{3}$, STEFANO DI TORE ${ }^{4}$, ARIO \\ FEDERICI ${ }^{5}$ \\ ${ }^{1}$ Department of Human Sciences, University of Urbino "Carlo Bo", Italy \\ ${ }^{2}$ Graduated of Physical Sciences University of Urbino "Carlo Bo", Italy \\ ${ }^{3}$ Clinical Psychologist graduated of Education Sciences University of Urbino "Carlo Bo", Italy \\ ${ }^{4}$ Department of Human, Philosophical and Educational Sciences of the University of Salerno, Italy \\ ${ }^{5}$ Department of Biomolecular Sciences, University of Urbino "Carlo Bo", Italy
}

\begin{abstract}
Valentini M, Mezelani E, Marciani G, Di tore S, Federici A. School: a coloured world af a everyday reality performance analysis: motor project of educational research for an effective integration. J. Hum. Sport Exerc. Vol. 7, No. Proc1, pp. S128-S139, 2012. The main purpose of this paper is to highlight the socializing value of motor activity, a factor often overlooked in the planning of the Italian school. To achieve this goal, we developed a research project that can rigorously demonstrate a range of aspects that we believe interesting in school after training experiences in schools. In detail, we will present a course of socialization in classes at the beginning of primary school. To keep up-to-date with the everyday life, and after several researches in the area, we realized that a growing number of foreign students populate classes, so we decided to make a choice even though it may seem "uncomfortable" allowed us to expand our field of investigation to a reality that we can not escape. We worked in an area of "frontier", in fact, the project has been extended to the Institute located in the Municipality of Osimo. That presents a progressive increase in the number of foreign students, which accounted for $7.5 \%$ to 31/12/2009 of the resident population which consists of a total of 33000 inhabitants. Beyond the knowledge of the language of their adopted country, in the case of the Italian which is an essential prerequisite for an effective and successful school placement of foreign students, we give importance to recreational motor path in an effort to facilitate mutual understanding and social relationships in children of primary school. We also believe that the motor game, in our case, traditional and collaboration can respond to the need to be united to another, without creating an opposition between the players who are trying to achieve a common goal. Key words: GAME, PHYSICAL EDUCATION, ETHNIC GAME, PRIMARY SCHOOL.
\end{abstract}

\footnotetext{
Corresponding author. Via Mainardi, $16-61029$ Urbino (PU) Italy.

E-mail: manuela.valentini@uniurb.it

6th INSHS International Christmas Sport Scientific Conference, 11-14 December 2011. International Network of Sport and Health Science. Szombathely, Hungary

JOURNAL OF HUMAN SPORT \& EXERCISE ISSN 1988-5202

(c) Faculty of Education. University of Alicante

doi:10.4100/jhse.2012.7.Proc1.14
}

VOLUME 7 | Proc1 | 2012 | S128 


\section{INTRODUCTION}

The obvious increasingly presence of foreign children in our schools is inserted as a dynamic phenomenon in a situation characterized by profound social, cultural transformations of educational organization. The fluidity of a phenomenon in constant evolution is accompanied by the first signs of stabilization of the migration process, both for projects and life choices of households, and for the growing share of children of immigrant origin born in Italy and do in our schools the entire course of studies. The presence of foreign children in the classroom should be an opportunity for enrichment, growth and maturation that should not be overlooked or seen as a foreign element in the normal school curriculum for all those working in schools.

The theme we have introduced, which is that of school integration in the presence of students of different cultures, brings to attention a lively debate that has characterized the evolution of the school in recent decades, focused on the treatment of differences across learning and the right to education. Although this theme is markedly interdisciplinary, it is crucial for us to highlight the educational value of motor education, an aspect little recognized in our society. The school is at the heart of our analysis, the starting point is represented by the Comprehensive Institute "Bruno da Osimo" with primary school pupils. Studies argue that the school can create a favorable climate and a feeling of common belonging among students that can help to dispel those prejudices. The land on which you are to live together, Italians and foreigners, can become what you would call in pedagogical terms a "background integrator", that is to say a background able to "hold together" the differences that characterize different groups and individuals who live there (Zoletto, 2007). The main purpose of this paper is to highlight the educational value of the motor education on the socio-relational side, often neglected factor in the schedules of the Italian school. We decided to operate in a socio-cultural context with a high rate of immigration, we strongly believe that the motor joyful, proactive game done as a cooperative, can also facilitate a "favorable climate" of input / learning, rather than then to competition and appear "crushed" about the sizes of self-affirmation, efficiency, self-control that are important aspects, but not the only that must be pursued, especially at the beginning of "school life" of children. From these considerations, it becomes necessary to implement the project of integration through the use of the traditional game with the first classes of primary school. The focus of research is to understand how children of a small reality which is Osimo, socialize with each other during the hours of physical education, then observe their behavior dynamics and judge the importance of a subject less considered as a means of processes growth of immigrant children. The school seems to be a privileged place of study because it is within this education system that children define the processes of inclusion and exclusion, comparing biographies, cultures and form paths for the future. Despite at the beginning the school can be thought as a symbolic place where they condense the evolutionary paths, it is the basis for building a national and social identity of individuals. In the life of these children become so important relations between the partners and the fact that they become an integral part of their experience, which may prove to be active and creative individuals capable of giving meaning to everyday life at school through interaction with parents, teachers and peers.

Intercultural education is emerging as the ability to promote constructive coexistence and involves not only the acceptance and respect of diversity, but also recognition of its cultural identity, in the daily search for dialogue, understanding and cooperation, with a view of mutual enrichment.

Our project extends to seize the socialization of immigrant children in primary school during the hours of physical education. The focus of research is intercultural education that is created in an important context in which children, the main theme of our work, spend an important part of their time (Wallnöfer, 2000). To promote the social participation of children means, in fact, consider them complete people with a sense of 
responsibility in their choices, skills and ability to make requests. In a multicultural classroom, so it is likely that the complex nature of any interpersonal relationship increases: the tone of voice, gestures, eyes are problematic communication expression, since they originate from different cultural backgrounds and are not shared by all the actors that take part in the communication. The Comprehensive School "Bruno da Osimo" is attended by 71 foreign students who come from 24 different countries. Several educators and sociologists have studied the important role that sport and game take up for the socialization of foreign children. The sport can unite without distinction of any kind, even kids who do not speak the same language are held together by a common passion. Anthropology and cultural psychology (Rogoff, 2003) have long stressed the importance of games and play in the processes of socialization, in manners and times in which children and young people learn to move in the cultures and social relations in which they find to live. It is through play that the child carries out the experiences that are the basis of growth and development of his personality, and forms the basis of the preparatory work for the adult social behavior (Battacchi, 1986).

Through the game, the person is, therefore, indulged in his deepest needs:

-Movement
-Socialization
-Adventure
- Discovery
-Invention
- Creativity
-Dialogue and exchange of affection with the adult.

The disappearance of the traditional game goes together in a vicious spiral of cause and effect (Golding, 1997), in which the child manifests itself with devastating consequences:

-Lack of sensory-perceptual motor

- Lack of socialization

-Oppression of inventiveness, creativity and design

-Atrophy of fantasy and imagination

- Lack of emotional-affective gratification

-Difficulty of intellectual and language - lexical growth

-Inadequate development of the moral conscience moral and civil conscience

In the game, the subject experiences his own body in a symbolic way, in relation with others and to the world, starting from the experiences of the body, lived as a totality, and loaded with all its emotional content, the various mental functions emerge. The play and physical activity are a great opportunity to socialize, as they facilitate the child's social availability, offering him the possibility of intense interpersonal relationships (Musse et al., 1976). This is how the school tries to achieve a real social-emotional integration, with operators that should ensure the development of interpersonal relationships, implementing projects discussed previously. Through the game, you discover the world, you enter into a relationship with your environment, with objects, with the people who inhabit it. The recreational activity returns to the subject a sense of belonging to a wider global audience. The game assumes, therefore, specific forms of communication. The game looked from the point of view of interaction with each other, took the name of "social mobility"(Loos \& Dell'Aquila, 1993). It is essentially based, in group play, in the relationship with peers, that may be of the same team, in this case, the rules require the cooperation, or the same team of 
opponents, and in this case the rules of the game require forms of opposition. In the game, the child learns to relate himself to objects and environment, is becoming more aware of his movements, of the ability of his body (coordination, balance), of the value of one's body as a means of communication (expressiveness, gestures , mimicry ...) learn of to relate to the "space" and in particular to strengthen the knowledge of those coordinates that govern it, but also to the "time", lived and spent... in the game we know, we invent, we identify ourselves, we build ...(Federici et al., 2004). The "Libro Bianco dello sport", a document published by the European Commission in 2007, clearly states that the sport can be considered "a tool for social inclusion" and can promote a "shared sense of belonging and participation" We got to choose this school after a long quantitative research on the percentage of foreigners in classes, we spent several months visiting primary schools within the province of Ancona and Macerata, which led us to choose one of Osimo, as it was resulted to be attended by many foreign children.

\section{MATERIAL AND METHODS}

With this research, we wanted to replay the need to ascertain the importance of motor, such as educational action in relation to the "small customers" to whom the work was addressed. The research involved a sample of about 70 children between 6 and 7 years, attending the first and second years of primary school at Osimo, divided into two groups:

- Working Group: first-class full-time and second class in normal time, respectively with 20 pupils, (with 6 foreign students) and 13 students (with 4 foreign students);

- Control group: first class ordinary-time and second class full-time, respectively with 19 students (with 5 foreign students) and 15 students (with 6 foreign students).

The working group has been engaged for five months, from November 6 to April 9, three times a week in physical education sessions lasting three hours each. To the working group have been proposed recreational motor - activities taking into account our experimental hypothesis. We want to monitor the development of socialization in the initial period of activity and then in the final one, to detect possible changes. We have proposed the use of Units of Learning focused of the traditional game (Staccioli, 2008). We wanted for our Learning Units use the traditional sports games because if you only proposes institutionalized activities (the so-called "sport" for excellence), rather than enrich the relational sphere, you would be reduced to just create relations of "pure " competition (Donald \& Mc Burney, 2004). We used for our purpose, even games that are part of traditional games, the so-called games or collaboration. The games of collaboration do not usually involve opposition between players because they are trying to achieve a common goal. Collaborate replies the need to be united to another, to take and give confidence to receive and provide help. Based on the body action, traditional sports games can count on the fun that stimulates more intensely the whole person regardless of age. Traditional sports games play social practices that, in all ages, will take place in everyday life. Each game resides on beliefs. This set of beliefs, this system of rules, is the basic contract is for the game, the "social contract" to which all practitioners have decided to join. In many cases, the regulation of the practice occurs within the group of the game itself, without any recourse to outside specialist arbitration. Appealing to the action, and more specifically to motor behavior, traditional sports games have the precious privilege of soliciting entirely different aspects of personality (Provost \& Villeneuve, 1980).

We can place the traditional game in different sizes: 
-organic dimension;

-cognitive dimension;

-affective dimension;

-relational dimension;

-expressive dimension.

What is the background to our research is the important feature that the traditional games highlight the cooperation and the success of any player, but does not seek an outcome that enhances dominance over others (Parlebas, 1997). The motor relationship between players are ambivalent: the player himself chooses his friends and his rivals, and in the course of the game can change them. The player keeps his autonomy and is freedom of decision. These two contradictory aspects of the motor interaction allows you to better understand the subtleties of social relationships. In traditional games there is not final domination of an opponent, but is a sought after act together, understood as the sharing of common recreational adventure. Without missing a point no less import that is the acceptance of a system of rules set by playful the contract.

Classes subjected to our sample are as follows:

- Early phases of welcome;

- Warming up phase;

- The phase of center learning;

- Cool-down phase.

During the warming up phase, we proposed Teaching Units from the book "Corpo in cartella", with the general objective to develop and improve the ability to relate to others (Berna, 1997). The guiding hypothesis of our research can be formulated as follows: the motor recreational activity, particularly if conducted in the form of traditional sports, can materially chance the social interactions of a group. We have adopted a mixed research design, quantitative and qualitative. On the one hand, the "skeleton" of the work had a classical experimental form, with two control groups and a work group, both on the other hand teachers and drawings we asked to do, have provided to us a very rich corpus of empirical evidences, gathered through observations, deductions and small interviews. At beginning and the end of the project, we administered tests (Table 1) derived from the collaboration with the clinical psychologist, each student was asked to specify a maximum of two classmates with whom they wanted to play, both in playful activities and speed paths, then one he would not play (a negative item or rejection).

Through the use of Excel spreadsheet software, we were able to conduct very detailed analysis of the isolated nodes issue, and the relationship between genders: 
Table 1

\begin{tabular}{|c|c|c|c|c|c|c|c|c|}
\hline Questions & Question 1 & Question 2 & Question 3 & Question 4 & Question 5 & Questions & Question 7 & Questions \\
\hline $\begin{array}{l}\text { User } \\
\text { orsaneril }\end{array}$ & Gabriele & \begin{tabular}{|l|} 
Filippo,Nico \\
las
\end{tabular} & $\begin{array}{l}\text { Filippo,fram } \\
\text { Cesoo }\end{array}$ & Nicolas & Filippo & Gabriele & Nicolas & Loreneso \\
\hline $\begin{array}{l}\text { User } \\
\text { ondicolas }\end{array}$ & Vittorio & $\begin{array}{l}\text { Foderioo, Vitt } \\
\text { orio }\end{array}$ & $\begin{array}{l}\text { Filippo, Vitto } \\
\text { rio }\end{array}$ & Gabriele & Filippo & Gianluxca & Filippo & Larenoso \\
\hline $\begin{array}{l}\text { User } \\
\text { ogemana }\end{array}$ & Erika & $\begin{array}{l}\text { Erika,Marg't } \\
\text { erita }\end{array}$ & $\begin{array}{l}\text { Margberitase } \\
\text { milia }\end{array}$ & Erika & Emilia & Marngherita & Erika & Ismail \\
\hline $\begin{array}{l}\text { User } \\
\text { osiendexes }\end{array}$ & Filippo & $\begin{array}{l}\text { Filippo,Fede } \\
\text { rico }\end{array}$ & \begin{tabular}{|l} 
Gabricle,sism \\
ail
\end{tabular} & Federico & Gabriele & Vittorio & Filipplo & Prapti \\
\hline $\begin{array}{l}\text { User } \\
\text { oElema }\end{array}$ & Emilia & $\begin{array}{l}\text { Ginevra,Fmil } \\
\text { ia }\end{array}$ & $\begin{array}{l}\text { Gabriele,Fili } \\
\text { ppo }\end{array}$ & Filippo & Fimilia & Ginevra & Filippo & Lorencoso \\
\hline $\begin{array}{l}\text { User } \\
\text { Omhalek }\end{array}$ & Germa & \begin{tabular}{|l|} 
Flena, Germm \\
a
\end{tabular} & $\begin{array}{l}\text { Erika, Germm } \\
\text { a }\end{array}$ & Flenas & Fmilia & Germa & Gemma & Lorencoso \\
\hline $\begin{array}{l}\text { User } \\
\text { Optreapei }\end{array}$ & Enika & Fmilia, Erika & \begin{tabular}{|l} 
Vittoriojilip \\
po
\end{tabular} & Filippo & Filena & Erika & Erika & Gianluca \\
\hline $\begin{array}{l}\text { User } \\
\text { ovittorio }\end{array}$ & Gabriele & $\begin{array}{l}\text { Filippo, } \\
\text { Gabriele }\end{array}$ & $\begin{array}{l}\text { Giantiva,Ga } \\
\text { briele }\end{array}$ & Filippo & Gĩanlinca & Gabriele & Germma & Prapti \\
\hline $\begin{array}{l}\text { User } \\
\text { OLorenzo }\end{array}$ & Filippo & \begin{tabular}{|l|} 
Gabriele, Vitt \\
orio
\end{tabular} & $\begin{array}{l}\text { Giantivea, Vitt } \\
\text { orio }\end{array}$ & Filippo & Filippo & Gabriele & Filippo & Ismail \\
\hline $\begin{array}{l}\text { User } \\
\text { ofederico }\end{array}$ & Jacopo & \begin{tabular}{|l|} 
Filippojacos \\
po
\end{tabular} & $\begin{array}{l}\text { Gianliaca,Fili } \\
\text { ppo }\end{array}$ & Filippo & Giantinca & Framoessoo & Gabriele & Malek \\
\hline $\begin{array}{l}\text { User } \\
\text { OJacopo }\end{array}$ & Gabriele & $\begin{array}{l}\text { Filippo,Fede } \\
\text { rioo }\end{array}$ & $\begin{array}{l}\text { Gabriele,Fili } \\
\text { ppo }\end{array}$ & Giantreca & Giantioca & Federioo & Filippo & Ismail \\
\hline $\begin{array}{l}\text { User } \\
\text { ofilippo }\end{array}$ & Jacopo & \begin{tabular}{|l|}
$\begin{array}{l}\text { Foderioo, Ga } \\
\text { briele }\end{array}$ \\
\end{tabular} & $\begin{array}{l}\text { Francesco,jix } \\
\text { ika }\end{array}$ & Federioo & Gabriele & Jacopos & Vittorio & Lorencoso \\
\hline $\begin{array}{l}\text { User } \\
\text { OErika }\end{array}$ & Germma & \begin{tabular}{|l|} 
Gernma, Elen \\
\end{tabular} & $\begin{array}{l}\text { Marghterita, } G \\
\text { enama: }\end{array}$ & Ginevra & Giantinca & Gabriele & Margherita & Ismail \\
\hline $\begin{array}{l}\text { User } \\
\text { oflbjgail }\end{array}$ & Filippo & \begin{tabular}{|l|} 
Filippo,firam \\
oesco
\end{tabular} & $\begin{array}{l}\text { Filippo,firan } \\
\text { cesoo }\end{array}$ & Framoessoo & Filippo & Filippo & Filippo & Loreneso \\
\hline $\begin{array}{l}\text { User } \\
\text { Ofrancesco }\end{array}$ & Nicolas & \begin{tabular}{|l|} 
Filippo,Nico \\
Las
\end{tabular} & $\begin{array}{l}\text { Gianlinca,fili } \\
\text { ppo }\end{array}$ & Gabriele & Foderioo & Filippo & Foderioo & Prapti \\
\hline $\begin{array}{l}\text { User } \\
\text { omargherita }\end{array}$ & Emilia & Elena,Emilia & $\begin{array}{l}\text { Gabriele,Fili } \\
\text { ppo }\end{array}$ & Emilia & Ginevra & Filippo & Elena & Ismail \\
\hline $\begin{array}{l}\text { User } \\
\text { OrEvolien Gristive }\end{array}$ & Ginevra & \begin{tabular}{|l|} 
Margherita, E \\
lena
\end{tabular} & $\begin{array}{l}\text { GinevrasMar } \\
\text { gherita }\end{array}$ & Germma & Filippo & Gabriele & Margberita & Loreneso \\
\hline $\begin{array}{l}\text { User } \\
\text { oginema }\end{array}$ & Emilia & \begin{tabular}{|l|l|} 
Germma, Marg \\
herita
\end{tabular} & \begin{tabular}{|l} 
Emilia,Marg \\
berita
\end{tabular} & Fimilia & Giantisca & Nicolas & Margherita & Ismanil \\
\hline $\begin{array}{l}\text { User } \\
\text { OGabriele }\end{array}$ & Framoescoo & \begin{tabular}{|l|} 
GianlincajJac \\
opo
\end{tabular} & $\begin{array}{l}\text { Filippo,Frai } \\
\text { cespoo }\end{array}$ & Vittorio & Gianlisca & Vittorio & Federioo & Malek \\
\hline
\end{tabular}

The analytical work of social relations groups - classes, was also conducted through the use of some drawings, a tool that we used to obtain additional information, of a mainly qualitative type. It is known that to children of this age drawing represents an expressive privileged activity, therefore, can provide several useful elements (Quaglia, 2006). The four groups mentioned above, represented by the four classes were involved in the following way:

-Class first full-time which followed a traditional sports games program, where the groups were not fixed, but each lesson are altered, then the individual components are been constantly rotated within teams;

- Class second normal time where in this case the programming of the games was the same but with a high component of fixed cooperative groups, in which the companions have been always the same in all the lessons, as if they were real "teams ";

- The last two classes, first in normal time and the second full-time have been for us function of group of control group, on which we would not have taken place entirely (except for the initial and final tests).

What interests us is the quantity amount and quality of relationships highlighted before and after the educational activity, in order to point up any changes from recreational intervention.

oTest1: test performed before working on classes, in the period of November;

oTest2: testing performed at the end of the intervention in the period in April.

For each question and for each class we have compiled a sociometry (matrix see tables). 
Table 2

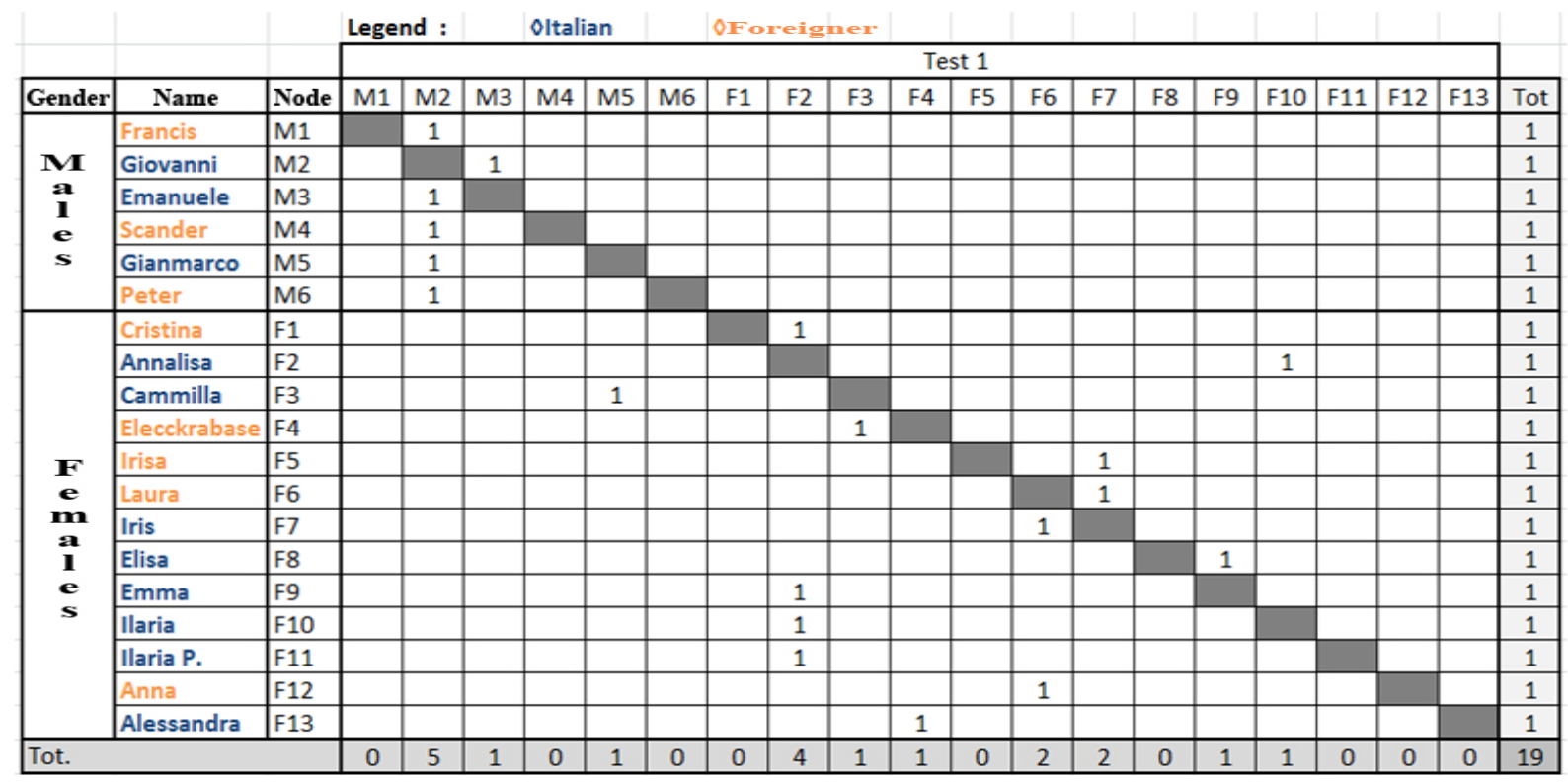

Together with the psychologist, we decided to enclose the question in the variables so we got this subdivision: choice of refusal (Question 8), choice of torque (questions 1,3,4), choice of sharing game (questions 6.7), choosing group play (questions 2.5). Then a sociometry matrix was built adding of all the choices of the questions belonging to that type of choice.

\section{Table 3}

Legend: Oltalian OForeigner

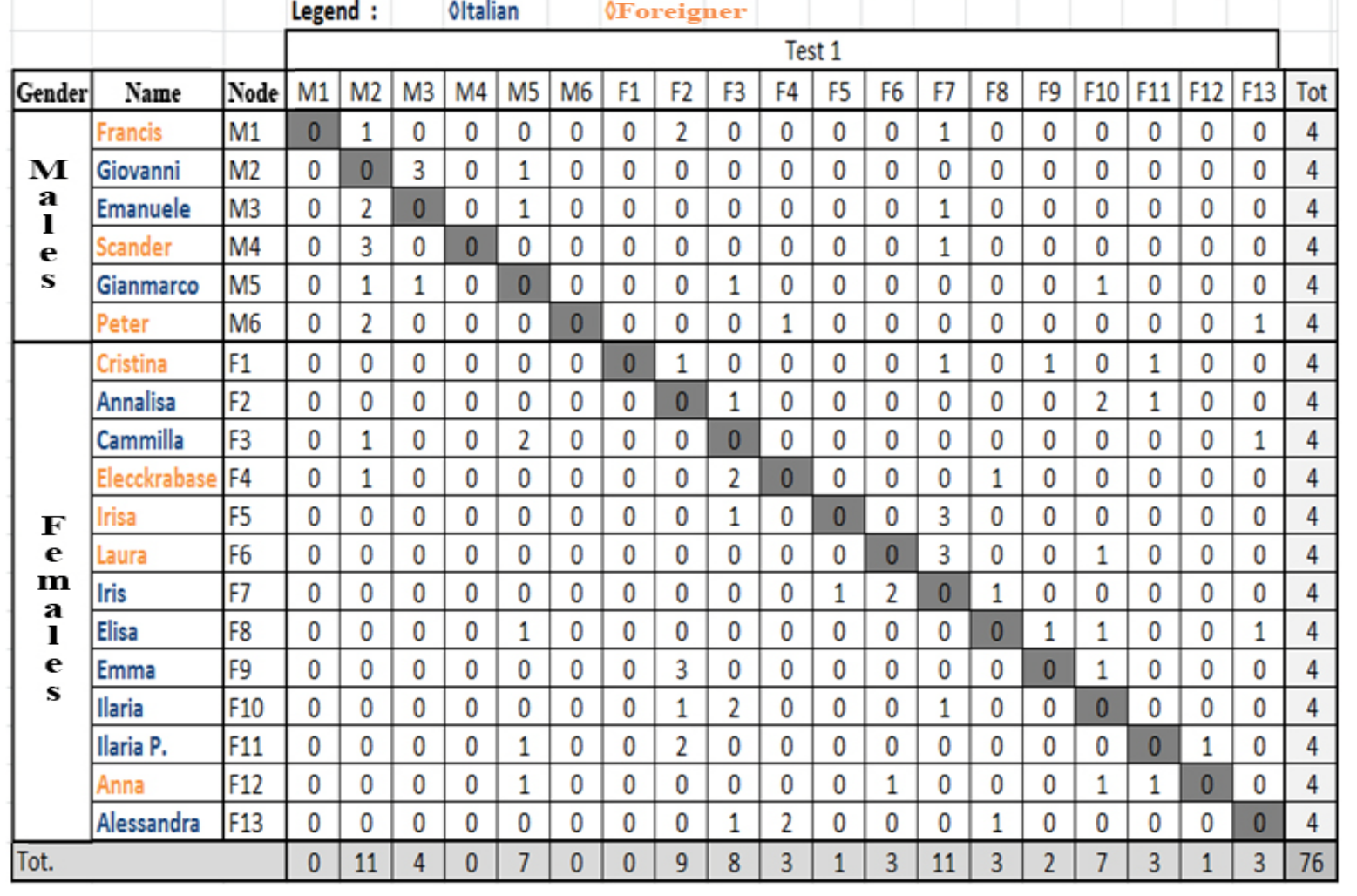




\section{RESULTS}

Choices were evaluated between Italians and foreigners by counting for each type of choice how many Italians chose Italians (ita-ita), how many Italians chose foreigners (ita-fore), how many foreigners chose Italian (fore-ita) and how many foreigners chose foreigners (fore-fore). A table has been built and calculated the percentage on the options total number of given by the members of the class (Italians or foreigners) multiplied by the number of questions for each type of choice (see Figures 1 and 2).

\section{Choice rejection- Italian- foreigner}

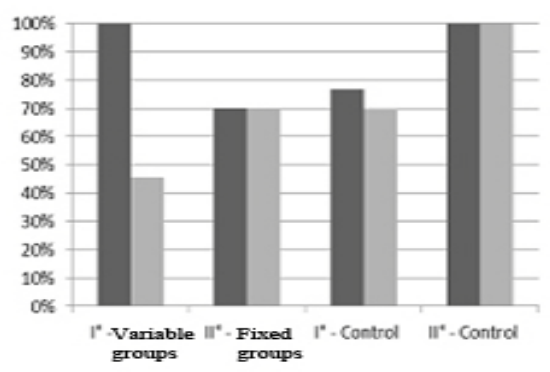

\section{Couple choice Italian-Foreigner}
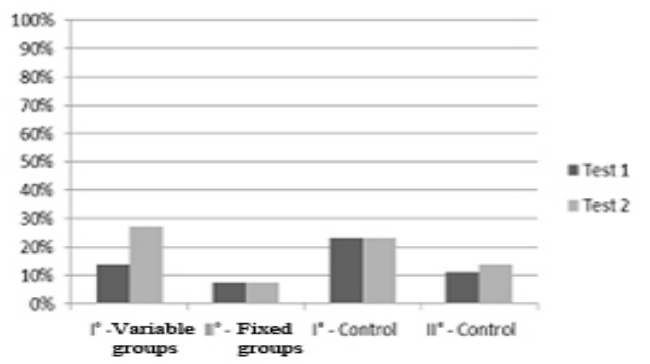

rejection- Italian- foreigner

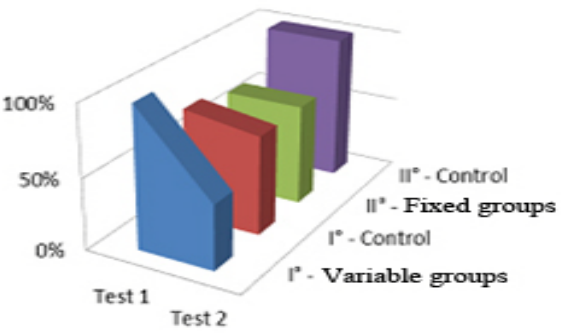

\section{Couple choice Italian-Foreigner}

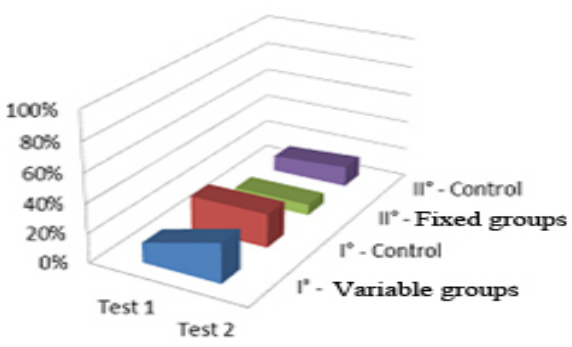

Figure 1

\section{Choice rejection- Italian- foreigner}

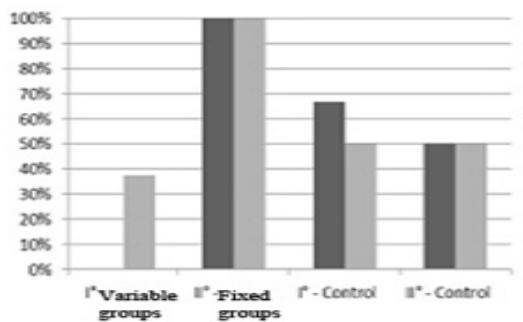

Couple choice Italian-Foreigner

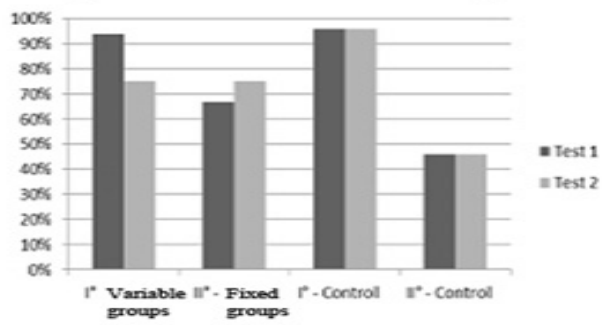

Choice rejection- Italian- foreigner

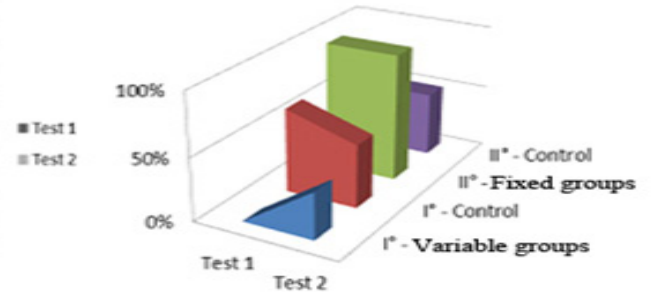

Couple choice Italian-Foreigner

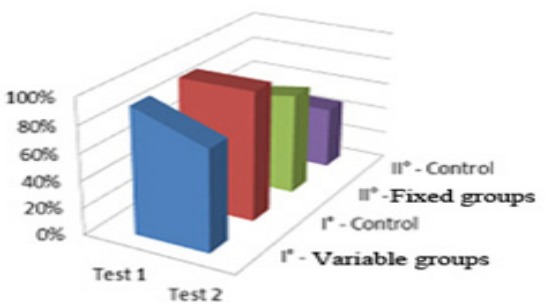

Figure 2 
We noticed that in the refusal choice to the first class - variable groups, the number of isolated nodes has been decreased after the activities. This means that after the activity with the variable group, the refusal is distributed on multiple members of the class and not on a small number of subjects.

According to the information given it is known as the first class - variable groups only $8 \%$ of Italian children choose foreigners in the first part of the test and this value doubles in the second test by switching to $16 \%$, in contrast to other classes in which almost anything does not change. This indicates a greater socialization between Italians and foreigners took place through the activity with variable groups. Our basic hypothesis, confirmed by the data collected suggests that the stability of relationships, gained through the invariance of the working groups, makes the child more capable of achieving reciprocity with mates. This hypothesis is supported by the improvement emerged from the group in the index of isolated nodes (see Figures 3-4).

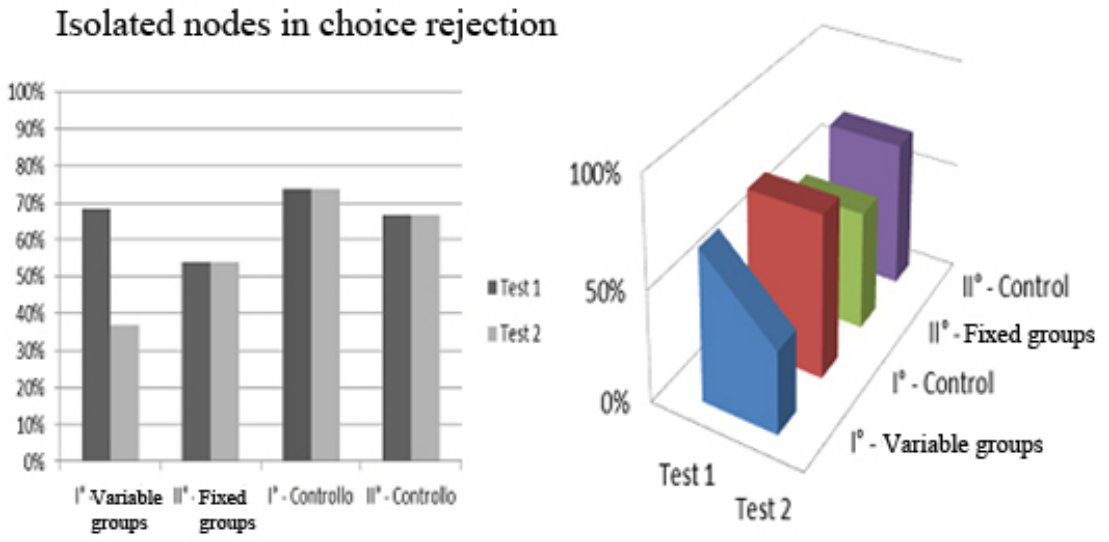

Isolated nodes in couple choice
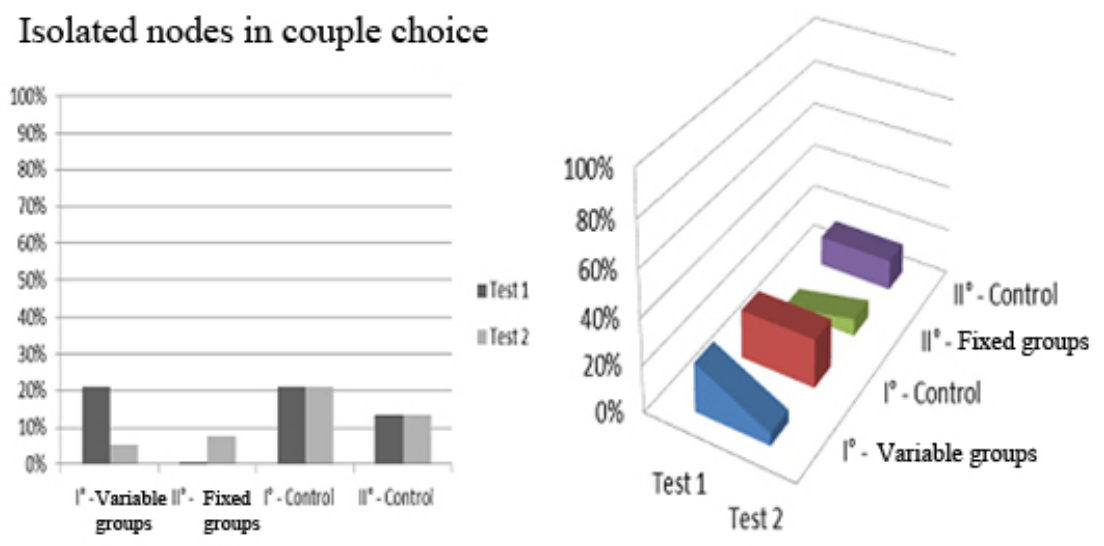

Figure 3 


\section{Choice Rjection}

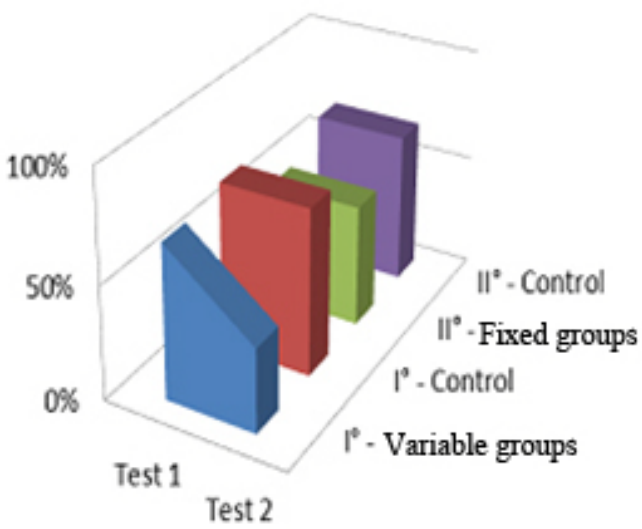

\section{Group game}

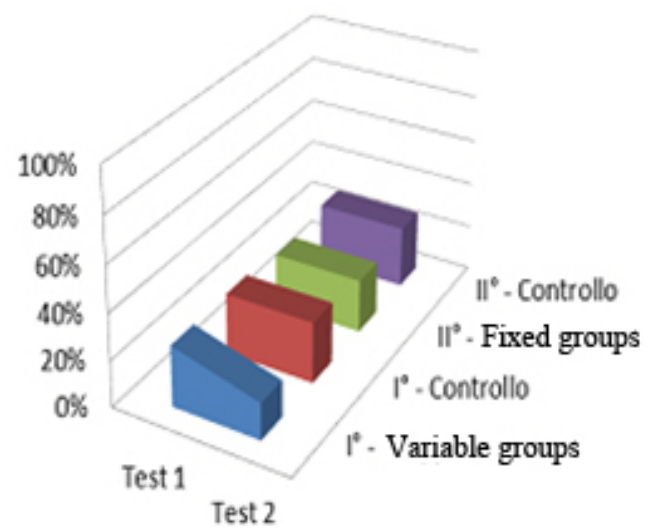

Couple choice

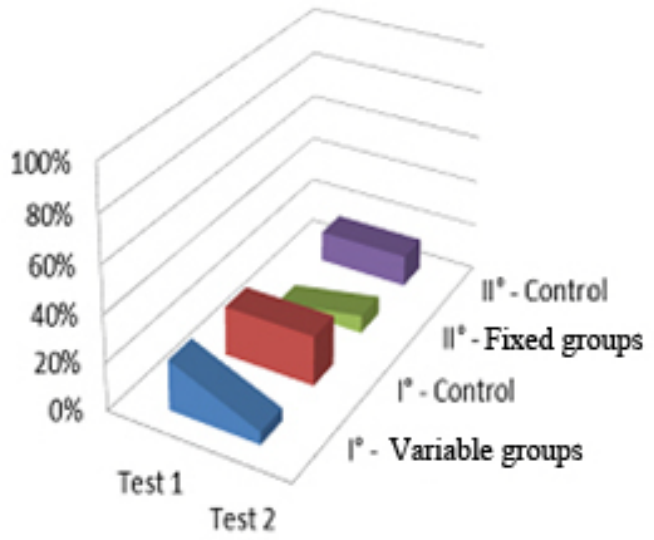

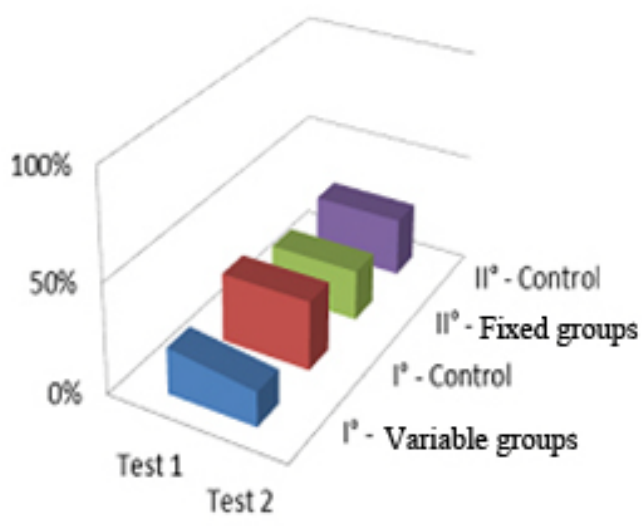

Figure 4

\section{DISCUSSION}

Children who have worked in fixed groups tend to maintain constant isolated subjects that in a similar situation, struggle more to integrate and create lasting relationships with others. So on the one hand, the activities in fixed groups seem to improve the number of links, but it is mainly thanks to the activities carried out with variable groups that children can expand the experiences of collaboration / cooperation with all partners, not just with some. Regarding the effect of opening of the relations between the children, the analysis of different types of choices between Italians and Italians, and strangers with strangers, pointed out that playful activities, in particular the traditional game, speed up the socialization among that children foreigner, though initially bind more to Italian children, then they increase the search for partners who, like them, come from elsewhere. This trend, present in both experimental classes is very stronger in the two ones that have suggested the traditional game, in contrast in the control classes foreigners increase the search for partners. 
In short, we seem to say that the organization of activities in relation to the stability and fixity of the working groups, is one of the principal key to stop the reciprocal relationship, and when it has been intervened with the variable group children were able to form relationships with their mates, go out of their prejudices to become friends at a later time. From the observation of diagrams (see Figure 5) clearly shows that in a first time Italians chose only Italians, then in the analysis of the second test the dynamic range is much reversed.

\section{Choice rejection- $1^{\circ}$ Variable groups}
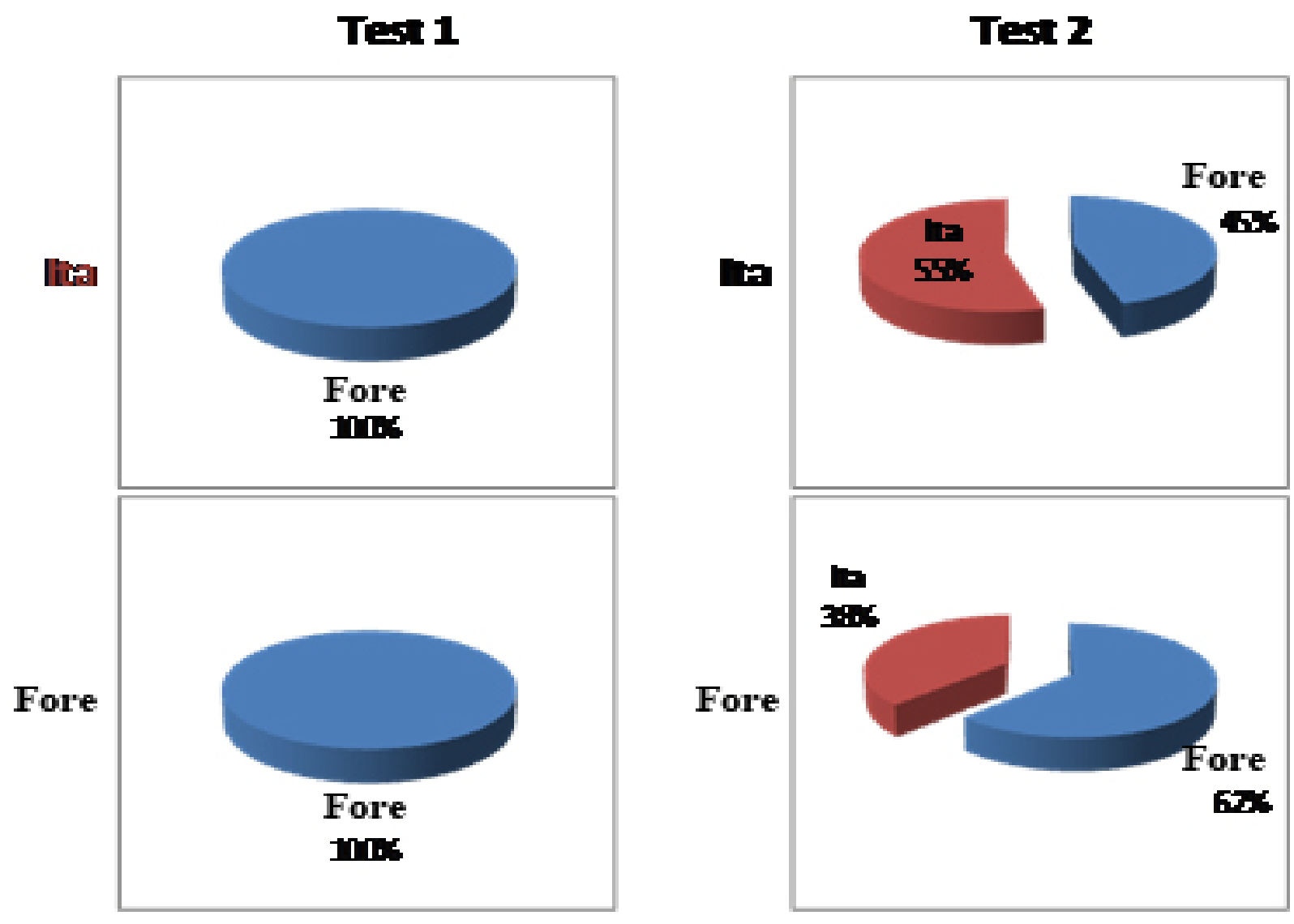

Figure 5

That Italians at a later time prefer to choose in their games only foreigners. This happened in the variable group, while little or nothing has happened in the other three groups. This shows a positive change after our work, which allowed the children to socialize with each other beyond, their fees as an immigrant child to marginalize. Playing together they had the opportunity to confront, relate, even talk and exchange informations, which does not happen in the other hours of lessons. This aspect, closely connected to an hour of physical education, in which we have invested in these five months, brought us once again to give more importance to a subject which in addition to improving motor capacities, which we have limited to observe, has a much more challenging role on the educational and relational sphere. Allows children to 
grow inside, to overcome the barriers that divide them with their foreign peers, to come out with their quality of social actors who can express themselves in a free manner. The enthusiasm shown for this matter of important educational value and after the results obtained, we pay to the attention to educators in this field so you do not leave out the methodology of teaching, which in this case it valued the benefit of the traditional game as a method.

\section{REFERENCES}

1. ALBAREA R, \& IZZO D. Manuale di pedagogia interculturale, ETS: Pisa; 2002.

2. BATTACCHI MW. II gioco. Ed. la nuova Italia: Firenze; 1986.

3. BERNA F. Il corpo in cartella. Educazione motoria nella scuola elementare, Edi-ermes;1997.

4. COTTINI L. Fare ricerca nella scuola. edizione Murzia; 2002.

5. DEMETRIO D, FAVARO G. Didattica Interculturale. Nuovi sguardi, competenze, percorsi, Franco Angeli: Milano; 2002.

6. DONALD H, BURNEY MC. Metodologia della ricerca in psicología. Edizione il Mulino; 2004.

7. DUCCIA D, FAVARO G. Bambini stranieri a scuola. Accoglienza e didattica interculturale nella scuola d'infanzia e nella scuola elementare. La Nuova Italia-Firenze; 1997.

8. FEDERICI A, TONINI-CARDINALI C, VALENTINI M. Non solo parole. Ed. Montefeltro; 2004.

9. LOOS S, DELL'AQUILA L. Naturalmente giocando. Alla scoperta dell'ambiente attraverso il gioco. Ed. Ega: Torino; 1993.

10. MELOSSI D, GIOVANNETTI M. I nuovi Sciuscià. Donzelli Editore; 2002.

11. PARLEBAS P. Gioco e sport. Ed. Capitello: Torino; 1997.

12. PARLEBAS P. Jeux, Sports et Sociétés. Lexique de Praxeologie Motrice. INSEP: Paris; 1998.

13. QUAGLIA R. Manuale del disegno infantile. Storia, sviluppo, significati. Torino: UTET; 2006.

14. SLEETER CE, DELGRADO BERNAL D. Critical pedagogy, critical race theory, and antiracist education. Implication for multicultural education. Chilood education; 2007.

15. VAN ZANTEN A. Modèles d'intégration et dynamiques multiculturelles dans les établissements scolaires en Europe dossier. Revue française de pédagogie; 2003.

16. ZOLETTO D. Straniero in classe. Ed. Raffaello Cortina: Milano; 2007. 